\title{
Ohralajikkeiden lakoalttiuden herkkyys ympäristöolosuhteille
}

\author{
Timo Hurme ${ }^{1)}$, Jukka Öfversten ${ }^{2)}$ ja Lauri Jauhiainen ${ }^{3)}$ \\ ${ }^{1)}$ MTT, Tutkimuspalvelut, 31600 Jokioinen, timo.hurme@mtt.fi \\ ${ }^{2)}$ MTT, Tutkimuspalvelut, 31600 Jokioinen, jukka.ofversten@mtt.fi \\ ${ }^{3)}$ MTT, Tutkimuspalvelut, 31600 Jokioinen, lauri.jauhiainen@mtt.fi
}

\section{Tiivistelmä}

Lajikkeiden erilaiset herkkyydet ympäristöolosuhteiden vaihtelulle kiinnostavat pääasiassa kahdesta syystä. Ensiksi, jos ympäristöolosuhteiden tiedetään olevan vakaat kasvukausittain, voidaan valita lajike, joka menestyy juuri kyseisissä olosuhteissa. Toiseksi, jos ympäristöolosuhteet vaihtelevat runsaasti kasvukausittain tai ovat tuntemattomat, voidaan valita lajike, joka on vakaa ympäristöolosuhteiden vaihtelun suhteen. Käytimme tässä tutkimuksessa virallisten lajikekokeiden tulosaineistoa vuosilta 1997-2004. Aineisto kattoi 14 yleistä ohralajiketta, joita oli viljelty yhteensä 14 koepaikalla. Viljalajikkeiden satoisuuden herkkyyttä ympäristöolosuhteiden vaihtelulle on tutkittu runsaasti. Tässä tutkimuksessa vertailimme lajikkeiden herkkyyksiä käyttäen vastemuuttujana binääristä lakomuuttujaa (ei merkittävää lakoa / merkittävä lako). Käyttämämme tilastolliset menetelmät perustuvat yleistettyihin lineaarisiin sekamalleihin, joissa käytimme vastemuuttujan ehdollista odotusarvoa selittävänä muuttujana kuvaamassa tietyn ympäristön olosuhteita. Näistä malleista saimme lajikekohtaisia estimaatteja sekä lakoalttiuden ympäristöherkkyydelle että kokonaislakoalttiudelle, eli lajikkeiden keskimääräiselle lakoalttiudelle tavanomaisissa viljelyolosuhteissa. Tulosten perusteella ohralajikkeiden välillä oli selviä eroja sekä lakoalttiuden ympäristöherkkyydessä että kokonaislakoalttiudessa. Käyttämäämme menetelmää voidaan lakoisuuden lisäksi soveltaa vastaavasti myös muille binäärisille vastemuuttujille, kuten esimerkiksi taudin esiintymiselle, mutta tautiaineistoa on vielä toistaiseksi vähemmän käytettävissä. Aineisto analysoitiin käyttäen SAS 9:n GLIMMIX-proseduuria.

Asiasanat: genotyyppi × ympäristö -yhdysvaikutus, paikallinen ennustaminen, herkkyys, lajiketestaus 


\section{Johdanto}

Lakoalttius vaihtelee ympäristöolosuhteiden funktiona. Tässä tutkimme, vaihtelevatko eri ohralajikkeiden lakoalttiudet eri tavoin ympäristön suhteen. Tätä lajikeominaisuutta kutsutaan ympäristöherkkyydeksi (esimerkiksi Finlay \& Wilkinson 1963).

Lajikkeiden erilaiset lakoherkkyydet ovat olennaisia kahdesta syystä. Ensiksi, jos ympäristöolosuhteet ovat ennustettavissa, voidaan valita viljeltäväksi sellainen lajike, joka on lakoalttiuden kannalta optimaalisin juuri kyseisissä olosuhteissa. Toiseksi, jos ympäristöolosuhteet ovat arvaamattomat, voidaan minimoida riskiä valitsemalla lajikkeita, jotka ovat vähiten herkkiä ympäristöolosuhteiden vaihtelulle.

Valittaessa lajikkeita viralliselle lajikelistalle arvioidaan yleensä kolmea kriteeriä: satoisuutta, taudinkestävyyttä ja lakoisuutta. Satoisuus on kriteereistä tärkein. Se liittyy läheisesti kasvuaikaan, koska lyhyillä kasvuajoilla sadot jäävät pienemmiksi. Niinpä satoisuuden arvioinnissa huomioidaan myös kasvuaika (1 päivä kasvuajassa $=2 \%$ sadossa).

Lajikkeiden satoisuutta on tutkittu laajalti, ja siihen sovelletut menetelmät ovat vakiintuneet. Satoa mitataan jatkuvana muuttujana. Satomittausten voidaan yleensä olettaa olevan normaalisti jakautuneita, jolloin niiden analysointiin on olemassa vakiintuneet menetelmät. Yleisimmin käytettyjä menetelmiä ovat lineaarinen regressio ja lineaariset sekamallit. Näitä menetelmiä on laajennettu myös lajikkeiden erilaisten ympäristöherkkyyksien arviointiin. Lineaariseen regressioon liittyviä menetelmiä ovat soveltaneet muun muassa Yates \& Cochran (1938), Finlay \& Wilkinson (1963) sekä Eberhart \& Russell (1966). Oman (1991) ja Gogel ym. (1995) olivat ensimmäisiä, jotka käyttivät lineaarisia sekamalleja genotyyppi × ympäristö -yhdysvaikutuksen tarkasteluun. Piepho $(1997,1998,1999)$ on selkeyttänyt ja laajentanut kyseisiä menetelmiä sekä esittänyt perusteltuja tapoja tarvittavien herkkyysparametrien estimoimiseen. Öfversten ym. $(1998,2002)$ ovat käyttäneet lineaarisia sekamalleja viljalajikkeiden satoisuuden paikalliseen ennustamiseen. Samoissa artikkeleissa ehdotetaan myös sadon ympäristölle ehdollisen keskiarvon käyttämistä luonnollisen ympäristön mittarina.

Tutkimuksessamme käytimme virallisten lajikekokeiden viimeisen kahdeksan vuoden koeaineistoa. Aineistossa on satomittausten lisäksi myös lako- ja taudinkestävyyshavaintoja. Käytännössä lakoisuutta mitataan arvioimalla silmämääräisesti koeruudun lakoprosentti. Kyseisiä mittauksia ei voida olettaa normaalisti jakautuneiksi. Viimeaikainen kehitys tilastollisissa menetelmissä ja ohjelmistoissa tarjoaa kuitenkin käyttökelpoisia menetelmiä myös muiden kuin normaalisti jakautuneiden muuttujien analysoimiseksi. Tässä tutkimuksessa ohralajikkeiden lakoisuutta analysoitiin käyttäen yleistettyjä lineaarisia sekamalleja, joissa on logit-linkki.

Saamamme tulokset mahdollistavat kunkin lajikkeen lakoalttiuden estimoinnin tiettyyn ympäristöön liittyvän odotetun keskimääräisen laon funktiona. Lajikkeiden välillä havaittiin merkittäviä herkkyyseroja, joita voidaan hyödyntää käytännön viljelyssä. Tuloksena saadaan lajikkeista selkeää lisätietoa, jota voivat hyödyntää sekä viljelijät että neuvojat lajikevalintoja tehdessään.

\section{Aineisto ja menetelmät}

Käytetty aineisto pohjautuu Maa- ja elintarviketalouden tutkimuskeskuksen (MTT) suorittamiin virallisiin lajikekokeisiin. Kyseistä aineistoa on kerätty yli 30 vuotta. Nykyään kokeita tehdään noin 20 koepaikalla ja vuosittain kokeita on kaikkiaan yli 100. Koeasetelmana on yleensä epätäydellisten lohkojen koeasetelma, jossa on kolme tai neljä kerrannetta. Tässä tutkimuksessa käytettiin vastemuuttujana koekohtaisia estimoituja keskiarvoja kuvaamaan eri lajikkeita.

Alkuperäisessä aineistossa oli kaiken kaikkiaan yli 300 ohralajiketta tai linjaa, joista suurin osa ei ole enää käytännön viljelyssä. Osalla uudemmista lajikkeista ei löytynyt tarpeeksi havaintoja tilastollista mallinnusta ajatellen. Niinpä käytimme ainoastaan lajikkeita, jotka olivat olleet mukana yli 35 kokeessa. Teimme kuitenkin muutaman poikkeuksen ja otimme mukaan lajikkeet EDEL, BOTNIA ja ERKKI, joista oli alle 35 havaintoa (32, 26 ja 19, järjestyksessä), mutta joilla oli aiemmin havaittu mielenkiintoisia lako-ominaisuuksia (Kangas ym. 2005). Lajikekokeissa käytössä olevan tavan mukaisesti (Kangas ym. 2005) käytimme aineistoa ainoastaan viimeisen kahdeksan vuoden osalta (1997-2004). Lopullisessa aineistossa oli mukana havaintoja 14 koepaikalta, kahdeksalta vuodelta ja 14:sta yleisesti viljellystä ohralajikkeesta (Taulukko 1). 
Taulukko 1. Tutkimusaineisto (Kangas ym. 2005)

\begin{tabular}{llllll} 
Lajike & Havaintomäärä & Vuodet & $\begin{array}{l}\text { Kasvuaika } \\
\text { (päiviä) }\end{array}$ & Pituus $(\mathrm{cm})$ & $\begin{array}{l}\text { Lako } \\
\text { (\% alueesta) }\end{array}$ \\
\hline Edel & 32 & $01,03-04$ & 90,8 & 78,8 & 11,1 \\
Optima & 46 & $97-04$ & 95,2 & 61,8 & 12,4 \\
Saana & 90 & $97-04$ & 89,8 & 66,7 & 14,9 \\
Tofta & 48 & $97-02$ & 93,4 & 65,8 & 16,9 \\
Kunnari & 89 & $97-99,01-04$ & 89,0 & 77,0 & 22,1 \\
Scarlett & 71 & $97-04$ & 91,8 & 64,8 & 23,2 \\
Kustaa & 65 & $97-01$ & 91,5 & 70,8 & 25,8 \\
Gaute & 40 & $01-04$ & 86,2 & 79,3 & 25,9 \\
Arve & 100 & $97-03$ & 83,5 & 77,8 & 28,1 \\
Jyvä & 60 & $97-04$ & 86,9 & 73,8 & 28,3 \\
Rolfi & 38 & $98-00,04$ & 83,0 & 70,9 & 32,3 \\
Erkki & 29 & $97-00,02-03$ & 86,8 & 75,7 & 37,4 \\
Pohto & 72 & $97-01$ & 87,5 & 69,9 & 39,2 \\
Botnia & 26 & $97-99,03$ & 88,5 & 75,6 & 48,2
\end{tabular}

Käyttämässämme aineistossa lakoontuminen oli mitattu arvioimalla silmämääräisesti koeruudun lakoprosentti. Alustavan tarkastelun perusteella totesimme kyseisen mittaustavan tuottavan toisinaan epätarkkoja ja subjektiivisia mittaustuloksia. Myös laon jakauma vaikutti riippuvan voimakkaasti arvioijasta. Säilyttääksemme suurimman osan informaatiosta ja päästäksemme eroon subjektiivisuuden aiheuttamista ongelmista päätimme muuntaa havaitut lakomittaukset kaksiluokkaiselle asteikolle. Jakaessamme lakoontumista kaksiluokkaiseksi muuttujaksi käytimme rajana 10 prosentin lakoa.

Lakoalttiuden analysoimisessa ja ennustamisessa käytimme tilastollista mallia $\operatorname{logit}\left(p_{i j}\right)=g_{i}+b_{i} w_{j}+d_{i j}$. Mallissa $p_{i j}$ on ympäristössä $j$ lajikkeen $i$ laon todennäköisyys, $g_{i}$ ja $b_{i}$ ovat lajikkeeseen $i$ liittyviä kiinteitä parametreja, $w_{j}$ on ympäristöön $j$ liittyvä normaalisti jakautunut latentti muuttuja ja $d_{i j}$ kuvaa satunnaista vaihtelua (selittämätöntä yhdysvaikutusta). Kaikkien $w_{j}$ ja $d_{i j}$ oletettiin olevan riippumattomia. Satunnaistermien $w_{j}$ ja $d_{i j}$ variansseja merkitään $\sigma_{w}^{2}$ :llä ja $\sigma_{d}^{2}$ :llä. Malli on yliparametrisoitu, mistä johtuen sen kaikkia parametreja ei voitu estimoida ilman erillistä rajoitetta. Käytännössä estimoitiin ensin $\lambda_{i}=b_{i} \sigma_{w}$ ja sovellettiin lineaarista rajoitetta $\bar{b} .=1$. Tällöin saatiin estimaatti $b_{i}$ :lle: $\hat{b}_{i}=\hat{\lambda}_{i} / \bar{\lambda}$. (Oman, 1991). Perusteluna tälle estimointitavalle oli, että kyseisellä tilastollisella mallilla on faktoriaalinen kovarianssirakenne, joka koostuu osista $\lambda_{i}=b_{i} \sigma_{w}$. Nämä osat sekä niiden varianssit ja kovarianssit voitiin estimoida SAS 9:n GLIMMIX-proseduurilla (Piepho 1997; SAS Institute, Cary, NC). Tässä sovellettua rajoitetta on käytetty aiemmin vastaavissa lineaaristen sekamallien tilanteissa (esimerkiksi Piepho 1997). Seurauksena rajoitteesta saatiin kaksi tavoiteltavaa ominaisuutta: (1) $g_{i}=\operatorname{logit}\left(p_{i}\right)$ ja (2) selittävien muuttujien $w_{j}$ keskiarvo on nolla.

Parametrien $b_{i}$ tulkinta on, että suuret parametrin arvot kuuluvat lajikkeille, jotka ovat keskimääräistä herkempiä latentin muuttujan $w_{j}$ kuvaamalle ympäristövaihtelulle. Muuttuja $w_{j}$ saa arvoja välillä $(-\infty,+\infty)$. Sen keskiarvo nolla kuvastaa keskimääräisiä ympäristöolosuhteita.

Tilastollisesta mallista saatiin $\hat{p}_{i j}=\hat{p}_{i}\left(w_{j}\right)=e^{\hat{g}_{i}+\hat{b}_{i}\left(w_{j}\right)} /\left(1+e^{\hat{g}_{i}+\hat{b}_{i}\left(w_{j}\right)}\right)$, jossa $\hat{p}_{i j}$ on lajikkeen $i$ lakoontumisen estimoitu todennäköisyys ympäristössä $j$. Ottamalla tästä keskiarvon yli $i$ :n ja käyttämällä tietoa $\bar{b} .=1$, saatiin $\hat{p}_{j}=\hat{p}\left(w_{j}\right)=e^{\bar{g} \cdot+w_{j}} /\left(1+e^{\bar{g} .+w_{j}}\right)$, jossa $\hat{p}_{j}$ on kaikkien lajikkeiden keskimääräinen estimoitu lakoontumisen todennäköisyys ympäristössä $j$. Tästä puolestaan 
saatiin $w_{j}=\log \left(\hat{p}_{j} / 1-\hat{p}_{j}\right)-\bar{g}$. Sijoittamalla tämän $\hat{p}_{i j}$ :n kaavaan lajikkeen $i$ laon todennäköisyys ympäristössä $j$ voitiin esittää seuraavasti:

$$
\hat{p}_{i j}=\frac{e^{\hat{g}_{i}+\hat{b}_{i}\left[\log \left(\frac{\hat{p}_{j}}{1-\hat{p}_{j}}\right)-\bar{g} .\right]}}{1+e^{\hat{g}_{i}+\hat{b}_{i}\left[\log \left(\frac{\hat{p}_{j}}{1-\hat{p}_{j}}\right)-\bar{g} .\right]}}
$$

Yllä oleva kaava esittää lajikkeen $i$ lakoalttiuden ympäristön $j$ keskimääräisen lakoalttiuden funktiona. Tätä kaavaa voidaan käyttää ennustamaan tietyn lajikkeen lakoalttiutta suhteessa ympäristöolosuhteisiin.

\section{Tulokset ja tulosten tarkastelu}

Parametriestimaatit $\hat{g}_{i}$ ja $\hat{b}_{i}$ esitetään Taulukossa 2.

Taulukko 2. Estimoidut parametrit $\hat{g}_{i}$ ja $\hat{b}_{i}$

\begin{tabular}{lll} 
Lajike & $\hat{g}_{i}$ & $\hat{b}_{i}$ \\
\hline Arve & 0,0519 & 1,0009 \\
Botnia & 0,3868 & 1,1490 \\
Edel & $-1,7448$ & 1,1916 \\
Erkki & $-0,0134$ & 1,0390 \\
Gaute & $-0,3246$ & 1,0562 \\
Jyvä & $-0,4195$ & 0,8400 \\
Kunnari & $-0,5953$ & 0,9761 \\
Kustaa & $-0,5666$ & 0,9692 \\
Optima & $-1,6859$ & 0,9232 \\
Pohto & 0,0530 & 1,0057 \\
Rolfi & 0,0400 & 0,9605 \\
Saana & $-1,0999$ & 0,9333 \\
Scarlett & $-0,6617$ & 1,0034 \\
Tofta & $-0,4974$ & 0,9520
\end{tabular}

Kaavan (1) ja edellisessä taulukossa esitettyjen parametriestimaattien avulla saimme muodostettua Kuvan 1, jossa jokaisen lajikkeen lakoalttius esitetään kasvupaikkaan liittyvän keskimääräisen lakoalttiuden funktiona. 
Kuva 1. Lajikkeiden lakoalttiudet kuvattuna kasvupaikkaan liittyvän keskimääräisen lakoalttiuden funktiona

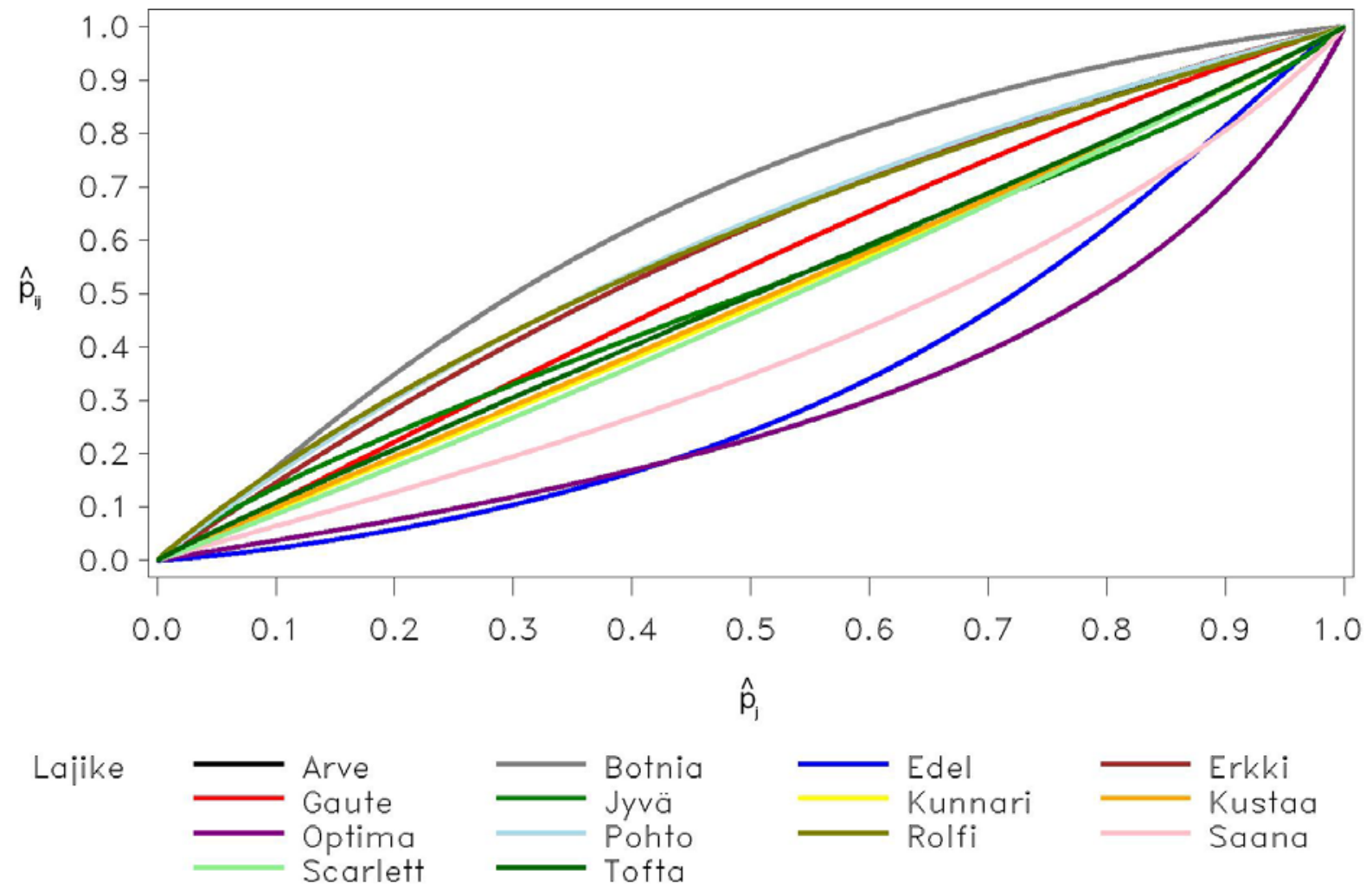

Kunkin lajikkeen lakoalttius riippuu kahdesta komponentista: vakiosta (mitataan $\hat{g}_{i}:$ :lä), joka kuvastaa lajikkeen lakoalttiutta keskimääräisissä ympäristöolosuhteissa, ja vaihtelevasta osasta (mitataan $\hat{b}_{i}:$ :llä), joka kuvastaa lajikkeen lakoalttiutta varsinaisissa kasvuolosuhteissa (Taulukko 2). Lajikkeet, joilla $\hat{b}_{i}$ saa pieniä arvoja, ovat vähemmän herkkiä ympäristölle kuin lajikkeet, joilla $\hat{b}_{i}$ saa suuria arvoja.

Saatujen tuloksien avulla lajikkeet voitiin laittaa paremmuusjärjestykseen niiden lakoalttiuden suhteen tietyissä ympäristöolosuhteissa (Kuva 1). Optimaalinen lajikevalinta riippuu siis ympäristöolosuhteista. Kuvasta 1 näemme muun muassa, että EDEL on paras valinta hyviin ympäristöolosuhteisiin, kun taas OPTIMA on paras valinta huonommissa ympäristöolosuhteissa. Kattavammin ilmaistuna voimme sanoa, että ympäristösidonnaisen lakoalttiuden ollessa pienempi kuin 0.45 EDEL on paras valinta, kun taas muulloin paras on OPTIMA. Näemme myös, että lajikkeen BOTNIA lakoalttius on vertailtavista lajikkeista suurin kaikissa ympäristöolosuhteissa.

\section{Johtopäätökset}

Tutkimme ohralajikkeiden erilaisia lakoalttiuksia erilaisissa ympäristöolosuhteissa. Vertailimme myös lajikkeiden lakoalttiuden herkkyyttä ympäristövaihtelulle. Tulosten avulla pystytään ennustamaan lajikkeen lakoalttius tietyissä ympäristöolosuhteissa ja havaitsemaan ympäristövaihtelun suhteen vähiten herkät lajikkeet.

Selittävänä muuttujana käytimme keskimääräistä lakoalttiutta tietyssä ympäristössä. Kyseessä on latentti muuttuja, joka yhdistää kaikki kyseiseen ympäristöön liittyvät ulkoiset vaikutukset. Vastaavaa menettelytapaa ovat aiemmin käyttäneet esimerkiksi Piepho (1997) ja Öfversten ym. (2002). Esitetyn latentin muuttujan käyttö on perusteltua, koska ei ole olemassa yksittäistä indeksiä, jonka avulla saataisiin riittävästi tietoa ympäristöstä kokonaisuutena (Eberhart \& Russell 1966).

Mallinnuksessa ja estimoinnissa hyödynnettiin aiempia analogisia tuloksia, jotka on kehitetty kevätvehnälajikkeiden sadonmuodostuksen paikalliseen ennustamiseen (Öfversten ym. 2002). Laajensimme kyseisiä menetelmiä yleistettyihin lineaarisiin sekamalleihin, erityisesti logit-malleihin. Näin pystyimme tarkastelemaan kaksiluokkaisella asteikolla mitattua lakomuuttujaa. 
Tulokset lakoalttiudesta eri ohralajikkeilla ovat käyttökelpoisia jo sinänsä, mutta lähestymistapaa voidaan käyttää myös muilla kasvilajeilla ja ominaisuuksilla. Muita kaksiluokkaiseksi muunnettavissa olevia viljojen ominaisuuksia ovat esimerkiksi taudin esiintyminen ja talvituhon suuruus. Kaksiluokkaiset mittaukset ovat usein tulkittavissa riskinarviointitilanteina. Esimerkiksi tutkittaessa sadonmuodostusta saatetaan olla kiinnostuneita tietyn satotason saavuttamisesta absoluuttisen sadon sijaan (Fox ym. 1997). Riskinarviointia käsitellään nykyään laajalti (esimerkiksi Piepho \& McCulloch 2004), ja suunnitelmissamme on soveltaa tässä esitettyjä menetelmiä jatkossa riskinarviointitilanteissa.

Tässä tutkimuksessa käytettyä raja-arvoa merkittävälle laolle (10 \%) on syytä tarkastella kriittisesti. Esimerkiksi Peltonen (1993) on tarkastellut artikkelissaan raja-arvojen määräämistä erilaisille kasvilajien ominaisuuksille.

Tämä tutkimus osoitti, että lajikkeiden välillä on eroja lakoalttiuden herkkyydessä. Kuitenkin merkittävämmät erot lajikkeiden välillä ovat kokonaislakoalttiudessa keskimääräisissä ympäristöolosuhteissa. Tällaisessa epälineaarisessa tilanteessa (logit) kahden parametrin tulkinta yksittäin ei kuitenkaan ole yhtä suoraviivaista kuin lineaarisissa malleissa. Tulosten tulkinta onkin käytännöllisintä tehdä tarkastelemalla molempia parametreja samanaikaisesti, eli tutkimalla lajikkeiden ennustettuja lakoalttiuksia tietyllä ympäristötasolla. Tällaista tarkastelua voidaan tehdä Kuvan 1 avulla. Jatkossa aiomme tutkia menetelmiä lajikkeiden paikallisten ennusteiden välisten erojen testaamiseen. Öfversten ym. (2002) ovat tehneet vastaavaa testausta lineaaristen mallien yhteydessä, mutta tässä tilanteessa testaaminen on monimutkaisempaa.

MTT:ssä on vielä paljon käyttökelpoista aineistoa jatkotutkimukseen myös muiden kasvilajien, lajikkeiden ja ominaisuuksien osalta. Nurmilla myös kasvilajien väliset herkkyyserot ovat sangen kiinnostava tutkimuskohde. Lisäksi uutta aineistoa kerätään vuosittain, esimerkiksi taudinkestävyydestä. Jatkossa pyrimme löytämään uusia menetelmiä, joita voidaan käyttää sekä vähiten herkkien että paikallisesti optimaalisten lajikkeiden valinnassa. Haluamme kiittää MTT:tä luvasta käyttää aineistoa tutkimuksessamme tähän asti.

\section{Kirjallisuus}

Eberhart, S.A. \& Russell, W.A. 1966. Stability parameters for comparing varieties. Crop Science 6: 36-40.

Finlay, K.W. \& Wilkinson, G.N. 1963. The analysis of adaptation in a plant-breeding programme. Australian Journal of Agricultural Research 14: 742-754.

Fox, P.N., Crossa, J. \& Romagosa, I. 1997. Multi-environment testing and genotype $\times$ environment interaction. In Statistical Methods for Plant Variety Evaluation (Eds R.A. Kempton \& P.N. Fox), pp. 117-138. London: Chapman and Hall.

Gogel, B.J., Cullis, B.R. \& Verbyla, A.P. 1995. REML estimation of multiplicative effects in multienvironment variety trials. Biometrics 51: 744-749.

Kangas, A., Laine, A., Niskanen, M., Salo, Y., Vuorinen, M., Jauhiainen, L. \& Nikander, H. 2005. Results of official variety trials 1997-2004. Agrifood Research Reports 83: MTT Agrifood Research Finland, Jokioinen, $193 \mathrm{p}$.

Oman, S.D. 1991. Multiplicative effects in mixed model analysis of variance. Biometrika 78: 729-739.

Peltonen, J. 1993. Partitioning of injuries caused by winter, fungal diseases and viral infections in cereals. Agricultural Science in Finland 2: 353-355.

Piepho, H.-P. 1997. Analyzing genotype-environment data by mixed models with multiplicative terms. Biometrics 53: 761-766.

Piepho, H.-P. 1998. Methods for comparing the yield stability of cropping systems - a review. Journal of Agronomy \& Crop Science 180: 193-213.

Piepho, H.-P. 1999. Stability analysis using the SAS system. Agronomy Journal 91: 154-160.

Piepho, H.-P. \& McCulloch, C.E. 2004. Transformations in mixed models: Application to risk analysis for multienvironment trial. Journal of Agricultural, Biological, and Environmental Statistics 9: 123-137. 
Yates, F. \& Cochran, W.G. 1938. The analysis of groups of experiments. Journal of Agricultural Science, Cambridge 28: 556-580.

Öfversten, J. 1998. Assessing sensitivity of agricultural crop varieties. Journal of Agricultural, Biological, and Environmental Statistics 3: 37-47.

Öfversten, J., Jauhianen, L., Nikander, H. \& Salo, Y. 2002. Assessing and predicting the local performance of spring wheat varieties. Journal of Agricultural Science, Cambridge 139: 397-404. 